\title{
Mechanical and thermomechanical properties of polyamide 6/Brazilian organoclay nanocomposites
}

\author{
Renê Anisio da Paz ${ }^{1}$, Amanda Melissa Damião Leite ${ }^{1 *}$, Edcleide Maria Araújo ${ }^{1}$, \\ Vanessa da Nóbrega Medeiros ${ }^{1}$, Tomás Jeferson Alves de Melo ${ }^{1}$ and Luiz Antônio Pessan² \\ 'Materials Engineering Department, Universidade Federal de Campina Grande - UFCG, \\ Campina Grande, PB, Brazil \\ ${ }^{2}$ Materials Engineering Department, Universidade Federal de São Carlos - UFSCar, \\ São Carlos, SP, Brazil \\ *amandamelissa.lins@yahoo.com.br
}

\begin{abstract}
Polymer/clay nanocomposites are a new class of composites with polymer matrices where the disperse phase is a silicate with elementary particles that have at least one of dimensions in nanometer order. Polyamide 6/Brazilian organoclay nanocomposites were prepared by melt intercalation, and the mechanical, thermal and thermomechanical properties were studied. The structure and morphology of the nanocomposites were evaluated by X-ray diffraction (XRD) and transmission electron microscopy (TEM). It was verified by XRD and TEM analysis that all systems presented exfoliated structure predominantly. By thermogravimetry (TG), nanocomposites showed higher stabilities in relation to pure polymer. It was observed that the nanocomposites showed better mechanical properties compared to the properties of polyamide 6 . The heat deflection temperature (HDT) values of the nanocomposites showed a significant increase in relation to pure polymer.
\end{abstract}

Keywords: nanocomposites, polyamide 6, HDT, organoclays.

\section{Introduction}

Polymer nanocomposites with clay are a new class of composites where the polymer matrix phase is dispersed silicate consisting of elementary particles which have at least one of its dimensions in the order of nanometers. The mineral particles commonly used in these materials are the smectite clays (montmorillonite, hectorite and saponite) in its particles lamellar morphology, with sides on the order of a micrometer and a thickness of approximately one nanometer ${ }^{[1,2]}$.

From the 60 s, the literature began to report the development of the first polymer/clay nanocomposites. From then until the present day, much attention has been given to polymer nanocomposites, especially those developed with layered silicates, due to the great need of modern materials of engineering and the fact that the pure polymers do not present the behavior or the properties required for certain application $^{[3-15]}$.

Organic/inorganic hybrids exhibit improved properties compared to the pure polymers or conventional composites, such as higher elastic modulus and tensile strength, higher resistance to solvents and flame resistance and good optical, magnetic and electric properties ${ }^{[4]}$. The improvement in the properties of these materials is achieved with a small load volume fraction (1-10\%), and due to very high aspect ratio of the load, i.e., length/diameter ratio that is high and increases the interaction with the polymer. Moreover, the polymer nanocomposites have the additional advantage that they can be processed with techniques and equipment used for conventional polymers ${ }^{[5-15]}$.

Polymer nanocomposites based on organoclays as a filler offer improved performance and opportunities for commercial applications $^{[16,17]}$. The key to significant enhancement in properties is to exfoliate the individual organoclay platelets into the polymer matrix to utilize their high aspect ratio and modulus ${ }^{[18]}$. The affinity between polymer matrix and organoclay is one of the most important factors in achieving good exfoliation; to a certain extent the affinity can be enhanced by optimizing the structure of the organoclay for a given polymer matrix. Previous studies have shown that semi-crystalline polyamides like nylon 6 , nylon 66 , nylon 11 , nylon 12 , etc. give rather good exfoliation ${ }^{[19,20]}$.

Polyamide 6 (PA6) is one of the most used types of aliphatic polyamide. The main applications of PA6 are in fibres, films, and as injection-moulded engineering plastic. PA6 crystallizes fast, usually up to percentages in the range of $30-40 \%$, providing a high modulus to the material even above the glass transition temperature $\left(\mathrm{T}_{\mathrm{g}}\right)$. One property common to all polyamides is that they absorb water from the environment, both from the air and from liquid water ${ }^{[21]}$.

The aim of this study was to prepare nanocomposites of polyamide 6 with three viscosity indexes and a Brazilian organoclay to evaluate the mechanical, thermal and thermomechanical properties. The use of Brazilian clay is the highlight and the differential of this work, whereas the literature as a whole frequently use commercial clay. The reason for the development of this work is the fact that the deposits of bentonite clay is abundant in South America. It is found in Brazil and therefore supplies the whole country with bentonite, and moreover it is essential to observe that the use of nanofillers brings benefits for the country and has a high technological and market importance. 


\section{Experimental}

It was used three polyamide 6 (PA6), Technyl C216 from Rhodia/SP, with viscosity index (VI) $=134 \mathrm{~mL} / \mathrm{g}$; and polyamide 6 from Polyform B300, with VI=140-160 mL/g and B400 with $\mathrm{VI}=235-265 \mathrm{~mL} / \mathrm{g}$, all in the form of granules of white coloration. The bentonite clay was Brasgel PA (sodium), $\mathrm{CEC}=90 \mathrm{meq} / 100 \mathrm{~g}$, provided by Bentonit União Nordeste (BUN), located in Campina Grande/PB/Brazil, in the form of powder passed in an ABNT 200 mesh sieve $(\mathrm{D}=0.074 \mathrm{~mm})$. The quaternary ammonium salt was Cetremide (hexadecyltrimethyl ammonium bromide). All materials containing polyamide were dried under vacuum at $80{ }^{\circ} \mathrm{C}$ for 24 hours.

The organoclay was produced from cation exchange reaction, where the sodium ions present in the clay are exchanged for ammonium ions of the quaternary salt. The Na-MMT as mixed in distilled water, was heated at $80 \pm 5^{\circ} \mathrm{C}$ and they were kept for 20 minutes with stirring to form a uniformly dispersed suspension. The salt equivalent to 1:1 CEC of Na-MMT as added into the dispersion. The mixture was stirred for more 20 minutes. After $24 \mathrm{~h}$ the mixture of bentonite and the salt were washed with distilled water for several times to remove the salt excess and it was dried at $60^{\circ} \mathrm{C}$ for $48 \mathrm{~h}$, and finally, passed in a sieve 200 mesh detailing of the procedure is described by Díaz $^{[22,23]}$ and others authors ${ }^{[8,11,15,24]}$.

In the nanocomposite preparation, before any processing step, all the materials with PA6 were dried in an oven with circulating air at $80^{\circ} \mathrm{C}$ for $1 \mathrm{~h}$. Afterwards, these materials were kept in an oven under vacuum at $80^{\circ} \mathrm{C}$ for $24 \mathrm{~h}$. The nanocomposites were prepared by two steps. Firstly, in order to assure a better dispersion of the fine clay powder in polyamide, a 1:1 PA6/organoclay master was previously produced in a Torque Rheometer Haake with internal mixer, at $240{ }^{\circ} \mathrm{C}$ and $60 \mathrm{rpm}$ for 10 minutes. After, PA6/organoclay nanocomposites, containing 3 and 5 wt. (\%) of clay, were melted in a corrotating twin-screw extruder operating at $240{ }^{\circ} \mathrm{C}$ and $250 \mathrm{rpm}$. After all the material has been extruded, granulated and dried at $80^{\circ} \mathrm{C}$ in a vacuum oven for 24 hours, it was submitted to the process of injection molding in Allrounder injection Arburg 270/30 ton, with the following injection conditions: injection pressure of $38 \mathrm{MPa}$; temperature profile of $250^{\circ} \mathrm{C}$; mould temperature of $65^{\circ} \mathrm{C}$; mould cooling of 20s; holding pressure of $32 \mathrm{MPa}$ and injection speed of $27 \mathrm{~cm}^{3} / \mathrm{s}$. The preparation of nanocomposites was according to literature ${ }^{[8,11,15,24]}$.

The thermogravimetry analysis (TG) was performed on a Thermal Analyzer TGA Q500 (TA Instruments), using about $5 \mathrm{mg}$ of sample heating rate of $20{ }^{\circ} \mathrm{C} \mathrm{min}-1$ and a sample holder of alumina. Samples were heated from room temperature to $900^{\circ} \mathrm{C}$ under nitrogen $\left(\mathrm{N}_{2}\right)$ gas at a flow rate of about $50 \mathrm{ml} \mathrm{min}^{-1}$. Clays and nanocomposites were characterized by X-ray diffraction (XRD) in XRD-6000 Shimadzu machine, using $\mathrm{K} \alpha$ radiation of the copper $(\lambda=1.542 \AA)$, voltage $40 \mathrm{kV}, 30 \mathrm{~mA}$, scan $2 \theta$ between $2-30^{\circ}$ and speed scanning at $2^{\circ} \mathrm{C} / \mathrm{min}$. The morphology of the nanocomposites were evaluated using the transmission electron microscope of the Philips CM120, operating at an acceleration voltage of $120 \mathrm{kV}$. Tensile tests were performed in accordance with ASTM D638-99 in a mechanical testing universal machine Instron 5569, with the deformation rate of $50 \mathrm{~mm} / \mathrm{min}$ and the samples were conditioned into a desiccator for 48 hours before to testing. The properties determined were: yield stress, elongation at break and Young modulus. The results were obtained from ten (10) samples. The analysis of differential scanning calorimetry (DSC) have been made in the DSC Q20 TA Instruments. The samples were first heated from room temperature up to $260{ }^{\circ} \mathrm{C}$ and kept for 1 minute before cooling down to room temperature. A second heating was used to observe the melting behavior of the PA6. All heating and cooling steps were done at $10^{\circ} \mathrm{C} / \mathrm{min}$. The Heat Deflection Temperature (HDT) was obtained according to ASTM D 648-01, HDT VICAT $6 \mathrm{P} / \mathrm{N} 6921$, CEAST model, $1.82 \mathrm{MPa}$, at $120^{\circ} \mathrm{C} / \mathrm{h}$, room temperature and up to $300^{\circ} \mathrm{C}$. The results were obtained from six (6) samples.

\section{Results and Discussion}

Generally, the processing temperature of the polymeric materials is higher than $150^{\circ} \mathrm{C}$, near the thermal limit of the organic salts. The structure of the quaternary ammonium ions is usually used with the objective to improve the compatibility with specific polymer. However, this molecular structure also determines its thermal stability. Figure $1 \mathrm{a}$ and $1 \mathrm{~b}$ illustrate the TG and DTG curves for untreated clays (MMT) and organoclay (OMMT). It is observed in Figure 1a that the
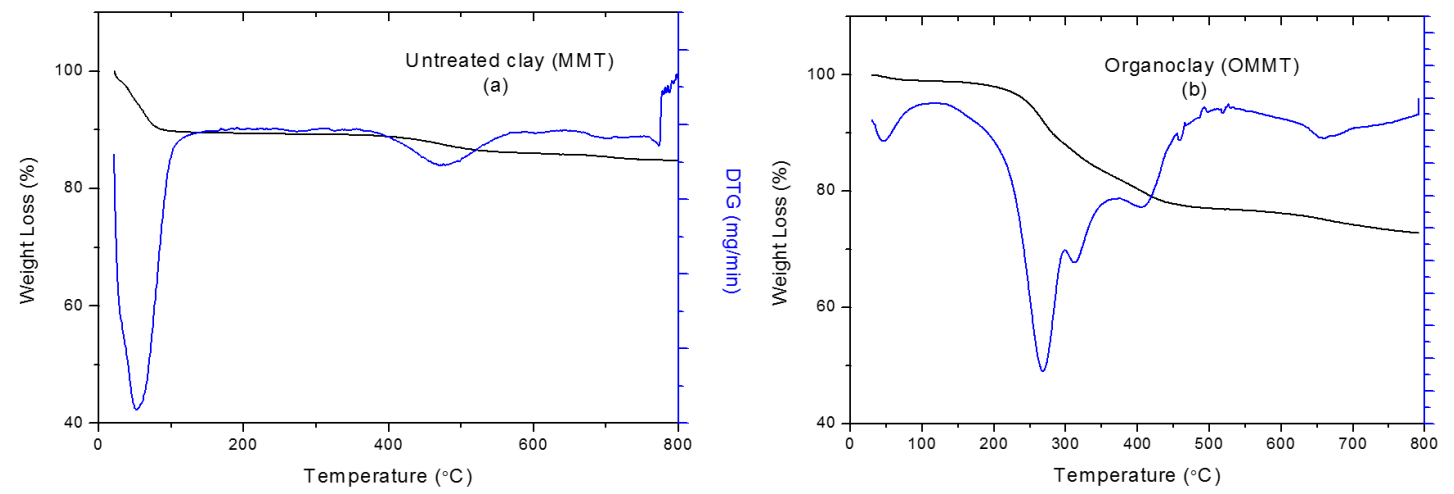

Figure 1. TG and DTG curves of (a) untreated clays and (b) Organoclay. 
MMT clay presents weight loss that occurs in the range of $30^{\circ} \mathrm{C}$ to $160^{\circ} \mathrm{C}$, corresponding to the loss of adsorbed water, and another the range of $400{ }^{\circ} \mathrm{C}$ to $600{ }^{\circ} \mathrm{C}$ corresponding to dehydroxylation the clay mineral with approximately $12 \%$ of weight loss. For organoclay (Figure $1 \mathrm{~b}$ ) the weight loss was $\sim 26 \%$, with a small weight loss below $100{ }^{\circ} \mathrm{C}$ corresponding to a residue of adsorbed water. It indicates that a small amount of clay was not modified by salt. A weight loss in the range of $180{ }^{\circ} \mathrm{C}$ to $460{ }^{\circ} \mathrm{C}$ with a maximum at $260^{\circ} \mathrm{C}$, corresponds to the decomposition of the quaternary ammonium salt and other weight loss in the range of $600^{\circ} \mathrm{C}$ to $750^{\circ} \mathrm{C}$, corresponding to dehydroxylation of clay mineral.

Through untreated and organoclay clays thermogravimetry analysis, the levels of water and organic salt incorporated were calculated. The untreated clays (MMT) presented a water content of approximately $10 \%$. On the other hand, organoclay (OMMT) water content was around $1.2 \%$ and $22.59 \%$ of organic salt. These results indicated that the hydrophilic characteristic of the clay was reduced.

The thermal decomposition of organoclays in general can be divided into four regions: 1) evaporation of adsorbed water and gaseous products under $180{ }^{\circ} \mathrm{C} ; 2$ ) evaporation of organic substances between $200{ }^{\circ} \mathrm{C}$ and $500{ }^{\circ} \mathrm{C}$; 3) aluminum-silicate dehydroxylation between $500^{\circ} \mathrm{C}$ and $700^{\circ} \mathrm{C}$ and 4) evaporation of the organic residues between $700{ }^{\circ} \mathrm{C}$ and $1000{ }^{\circ} \mathrm{C}^{[25,26]}$.

The results of TG and DTG of PA6 with three viscosity indexes and their nanocomposites with 3 and $5 \%$ clay are presented in Figures 2, 3 and Table 1. Three main characteristics are important: first, all samples exhibit the decomposition process, with the B300 5\% system exhibiting the highest thermal stability; the second, the process of decomposition of all samples occurs in the same temperature range, except for the $\mathrm{C} 2163 \%$ sample that it starts to decompose before. This result implies that the decomposition of PA6 was little affected by the addition of clay in this rate; and finally, when the temperature was above $350{ }^{\circ} \mathrm{C}$, the nanocomposites started to decompose at higher temperature than pure PA6, indicating increased thermal stability after incorporation of organoclay.

Similar decomposition behavior is exhibited by nanocomposites and can be attributed to the dispersion

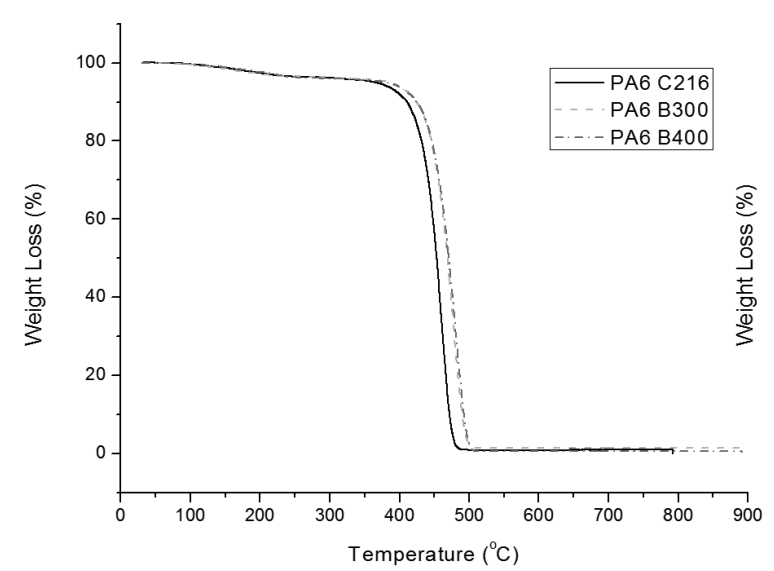

(a)

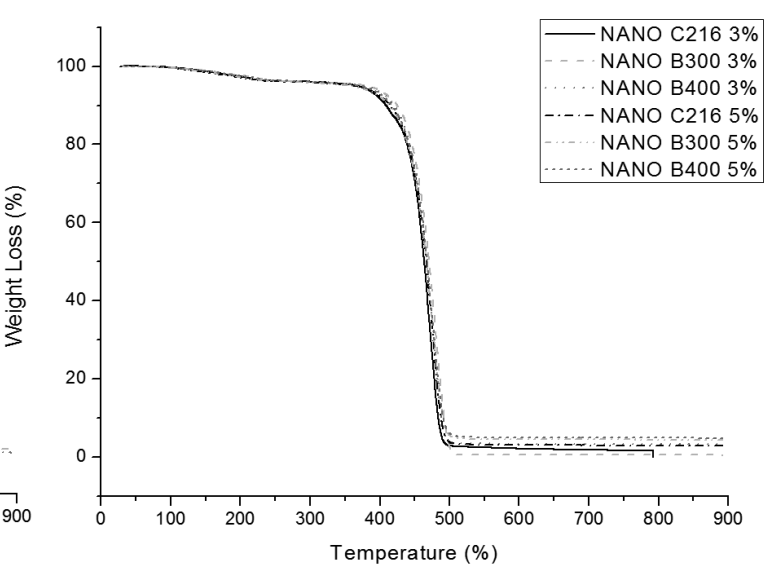

(b)

Figure 2. TG curves of (a) polyamide 6 with three viscosity indexes and (b) their nanocomposites with 3 and $5 \%$ clay.

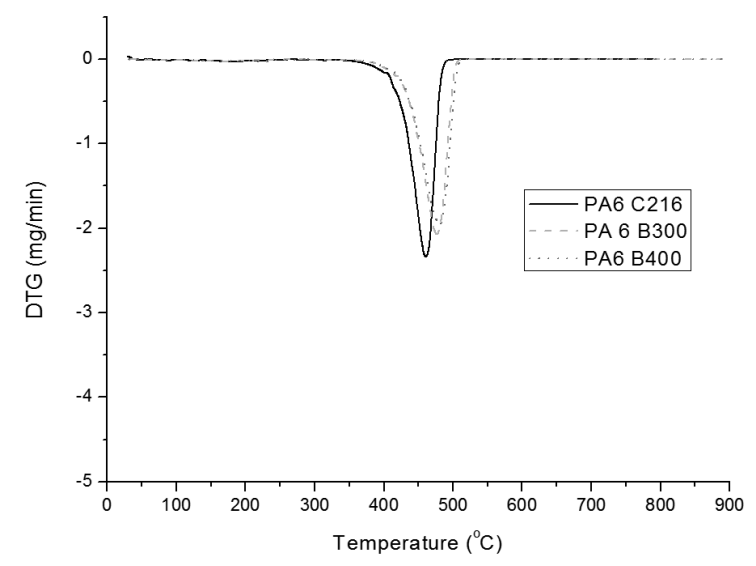

(a)

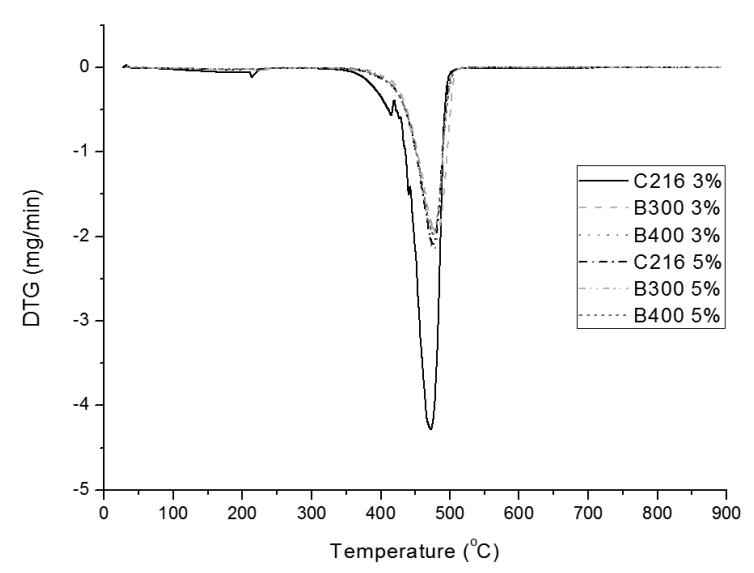

(b)

Figure 3. DTG curves of (a) polyamide 6 with three viscosity indexes and (b) their nanocomposites with 3 and $5 \%$ clay. 
of the clay layers within the matrix of PA6. The thermal stability enhancement of PA 6 after adding $5 \mathrm{wt} \%$ of clay was a consequence of the nano-scaled dispersion of layered clay, which resulted in oxygen and heat permeability reductions in the PA 6 matrix during the heating scans. The results of DTG are shown in the Figure 3a, b. It is observed that the TG shows a single peak with maximum weight loss, $\mathrm{T}_{\max }=430^{\circ} \mathrm{C}$ and $\mathrm{T}_{\text {onset }}=394^{\circ} \mathrm{C}$ for pure PA 6 . The presence of organoclay in the PA6 matrix changed to $\mathrm{T}_{\text {max }} \sim 480{ }^{\circ} \mathrm{C}$ e $\mathrm{T}_{\text {onset }}=406^{\circ} \mathrm{C}$ in all nanocomposites, i.e., higher stabilities compared to pure polymer. This evidences that different clay contents influence the thermal stability of materials. This behavior is in agreement with that reported by literature ${ }^{[27]}$ where they obtained similar results using systems with Cloisite 30B clay.

Figure 4a shows the XRD patterns of the clay untreated clays (MMT) and of the organoclay (OMMT). Making a comparison of the diffractograms, it is possible to visualize the efficiency of organophilization by increasing the basal interplanar distance $\left(\mathrm{d}_{001}\right)$ of the treated clay in relation to the untreated clay. The diffractograms of the untreated clay (MMT) shows characteristic peaks of bentonite containing accessory materials, such as quartz (Q) in the range of $22-30^{\circ}$, which occurs for all samples, and also a band at approximately $7.0^{\circ}$ that indicates the basal interplanar distance $\mathrm{d}_{001}$ of $12.63 \AA$, that is characteristic of montmorillonites containing $\mathrm{Na}^{+}$ions in the structure. Analyzing the diffractograms of the treated clay with Cetremide salt (OMMT), it is seen the peak shifts to smaller angles and consequent expansion of layers to $20.83 \AA$, due to penetration of the carbon chains attached to the quaternary ammonium salt, which favors the electrostatic interactions with the matrix, and it facilitates the incorporation of the polymer, according to the literature ${ }^{[4,8,11,15]}$.

Figure $4 \mathrm{~b}$ illustrates XRD patterns of polyamide 6 (PA6) and systems of PA6/organoclay (OMMT). It is noticed that the peak of the organoclay with $\mathrm{d}_{001}=20.83 \AA$ disappeared when it was incorporated at 3 and $5 \%$ concentration by weight in the matrix of polyamide 6 . These results can indicate that all systems exhibit exfoliated structure and/or partially exfoliated one ${ }^{[8-11,15]}$. It is interesting to note that the curves of the nanocomposites showed the same behavior, independently of the difference in molecular weight of PA. These results were confirmed by other works developed ${ }^{[8,10,11,15]}$. It can also be observed that in the range from $17^{\circ}$ to $26^{\circ}$, there are some peaks for the crystalline forms ( $\alpha$ - and $\gamma$-phases) of the polyamide 6 , wherein the monoclinic phase has distinct reflections ( $\alpha 1$ and $\alpha 2)$. For the injected material, the reflection peak of $\gamma$-phase was more intense, as observed

Table 1. TG results obtained for polyamide 6 with three viscosity indexes and their nanocomposites with 3 and $5 \%$ clay.

\begin{tabular}{|c|c|c|c|c|c|}
\hline Sample & $\begin{array}{c}\text { Clay content } \\
\%\end{array}$ & $\begin{array}{c}\text { Humidity } \\
\%\end{array}$ & $\begin{array}{c}\text { Organic Material } \\
\%\end{array}$ & $\begin{array}{c}\text { Decomposition } \\
\text { Temperature (peak) } \\
\left({ }^{\circ} \mathrm{C}\right)\end{array}$ & $\begin{array}{c}\text { Residues } \\
\%\end{array}$ \\
\hline \multirow{3}{*}{ PA6C216 } & 0 & 3.7 & 95.3 & 461.9 & 0.9 \\
\hline & 3 & 3.7 & 94.6 & 471.4 & 1.7 \\
\hline & 5 & 3.9 & 93.3 & 475.9 & 2.8 \\
\hline \multirow{3}{*}{ PA6B300 } & 0 & 3.7 & 94.9 & 477.2 & 1.4 \\
\hline & 3 & 3.8 & 93.9 & 478.4 & 2.3 \\
\hline & 5 & 3.8 & 91.8 & 475.9 & 4.4 \\
\hline \multirow{3}{*}{ PA6B400 } & 0 & 4.0 & 95.5 & 478.4 & 0.5 \\
\hline & 3 & 4.3 & 92.4 & 477.2 & 3.3 \\
\hline & 5 & 3.9 & 91.3 & 475.9 & 4.8 \\
\hline
\end{tabular}

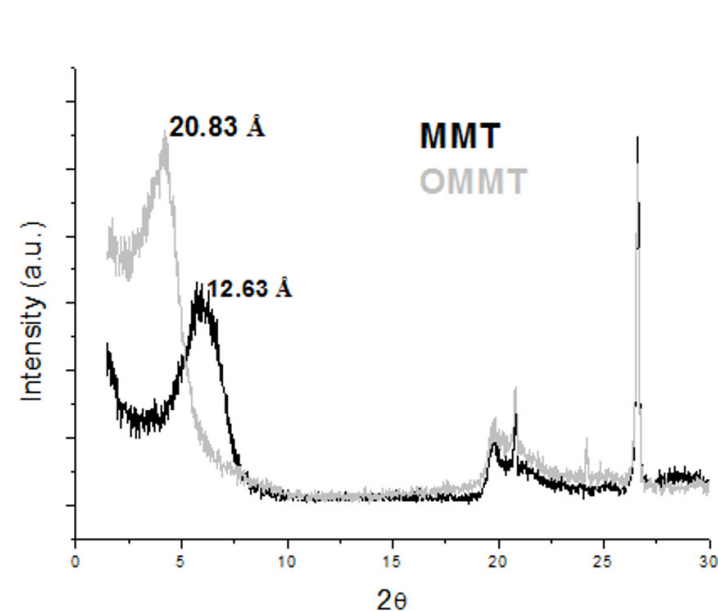

(a)

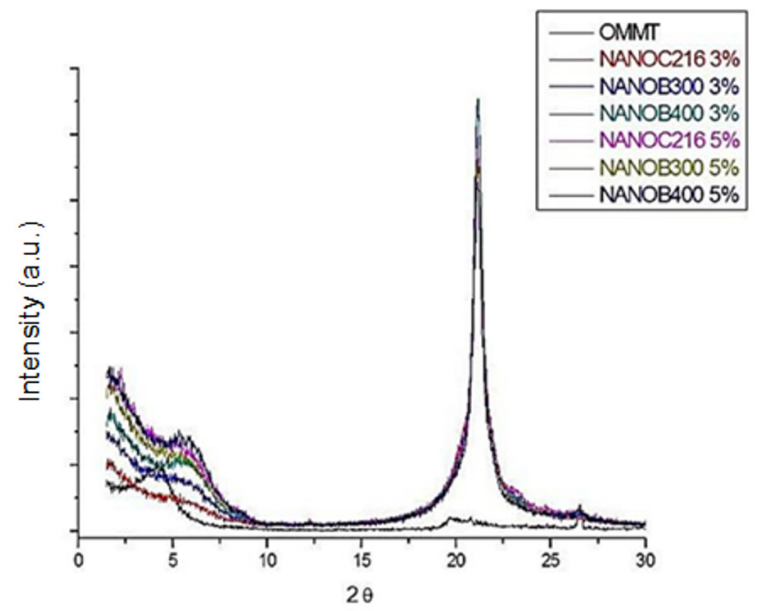

(b)

Figure 4. XRD patterns of pure PA6 and nanocomposites: (a) clays, (b) polyamides 6 with 3 and 5\% organoclay. 
in the literature. The formation of these two phases depends mainly on the crystallization conditions or addition of specific loads. The form of the $\alpha$ structure is known as the most thermodynamically stable $\mathrm{e}^{[8,10,15]}$.

Photomicrographs of PA6 C216 nanocomposite with $3 \%$ of OMMT (Figure 5a) and B300 system with 5\% clay (Figure 6b) show exfoliated morphologies with clay lamellae well distributed in the polymer matrix. The system PA6 C216 with $5 \%$ clay (Figure 5 b) shows a morphology partially exfoliated with exfoliated areas and intercalated structures in small areas. PA6 B300 nanocomposite with OMMT $3 \%$ (Figure 7a) presents a morphology composed of some exfoliated lamellae and some agglomerates of clay dispersed in the matrix. Already PA6 B400 nanocomposite with OMMT, $3 \%$ and $5 \%$ (Figure $7 \mathrm{a}$ and $7 \mathrm{~b}$ ) exhibit morphologies with exfoliated clay lamellae well distributed in the polymer matrix. According Fornes et al. ${ }^{[10]}$, the high molecular weight polymer and therefore its higher viscosity contributes to a higher shear or energy for separating the lamellae of the clay. Already the matrixes of smaller viscosities indexes do not allow complete exfoliation. These results confirm the results of X-ray diffraction, that is, confirms that the use of the two techniques is important in interpreting the type of nanocomposites formed.

The Table 2 presents HDT data obtained for the systems. The incorporation of clay into polymers generally

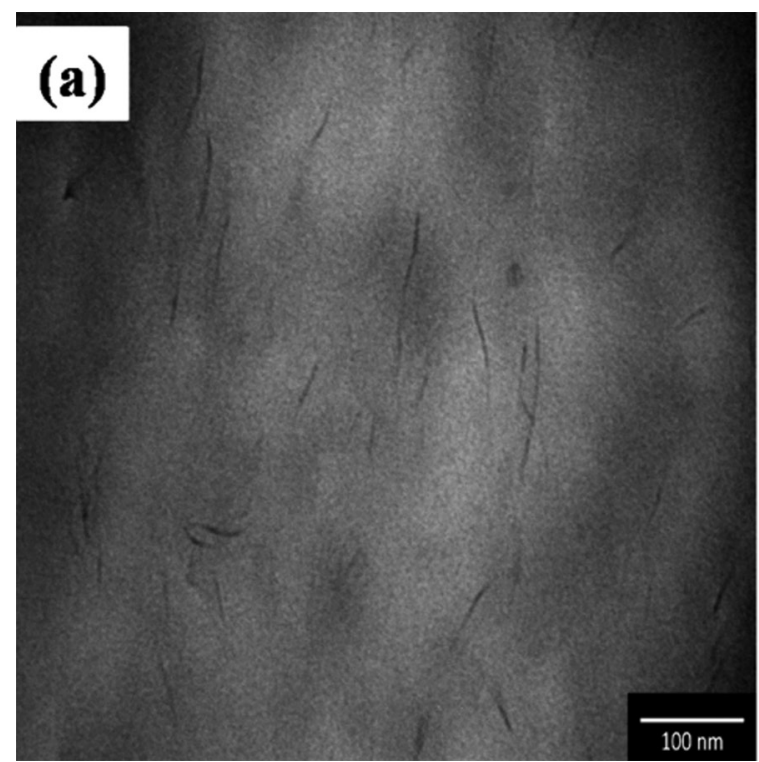

\section{(b)}

Figure 5. TEM photomicrographs of PA6 C216 nanocomposites with (a) 3\%, and (b) 5\% organoclay.
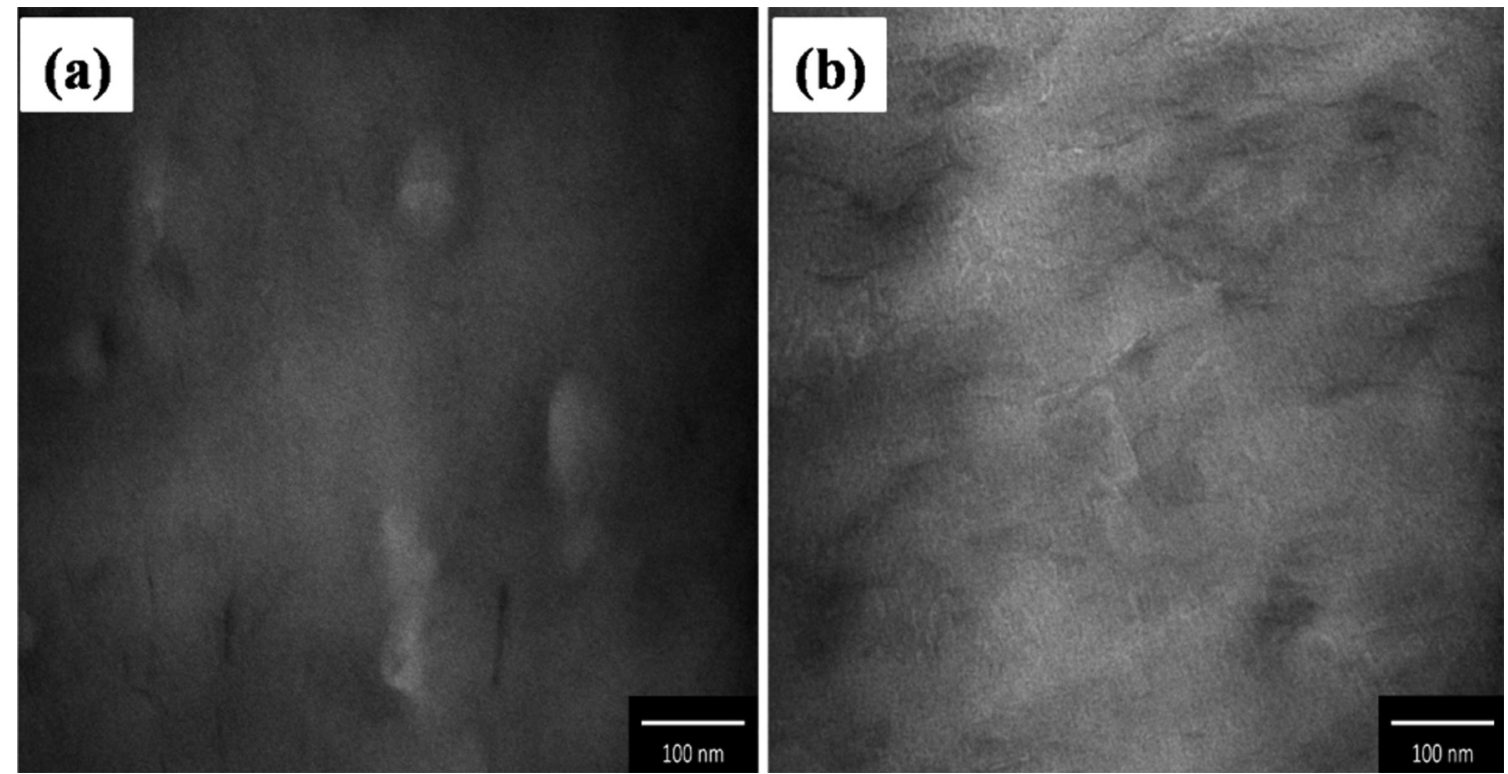

Figure 6. TEM photomicrographs of PA6 B300 nanocomposites with (a) 3\%, and (b) 5\% organoclay. 

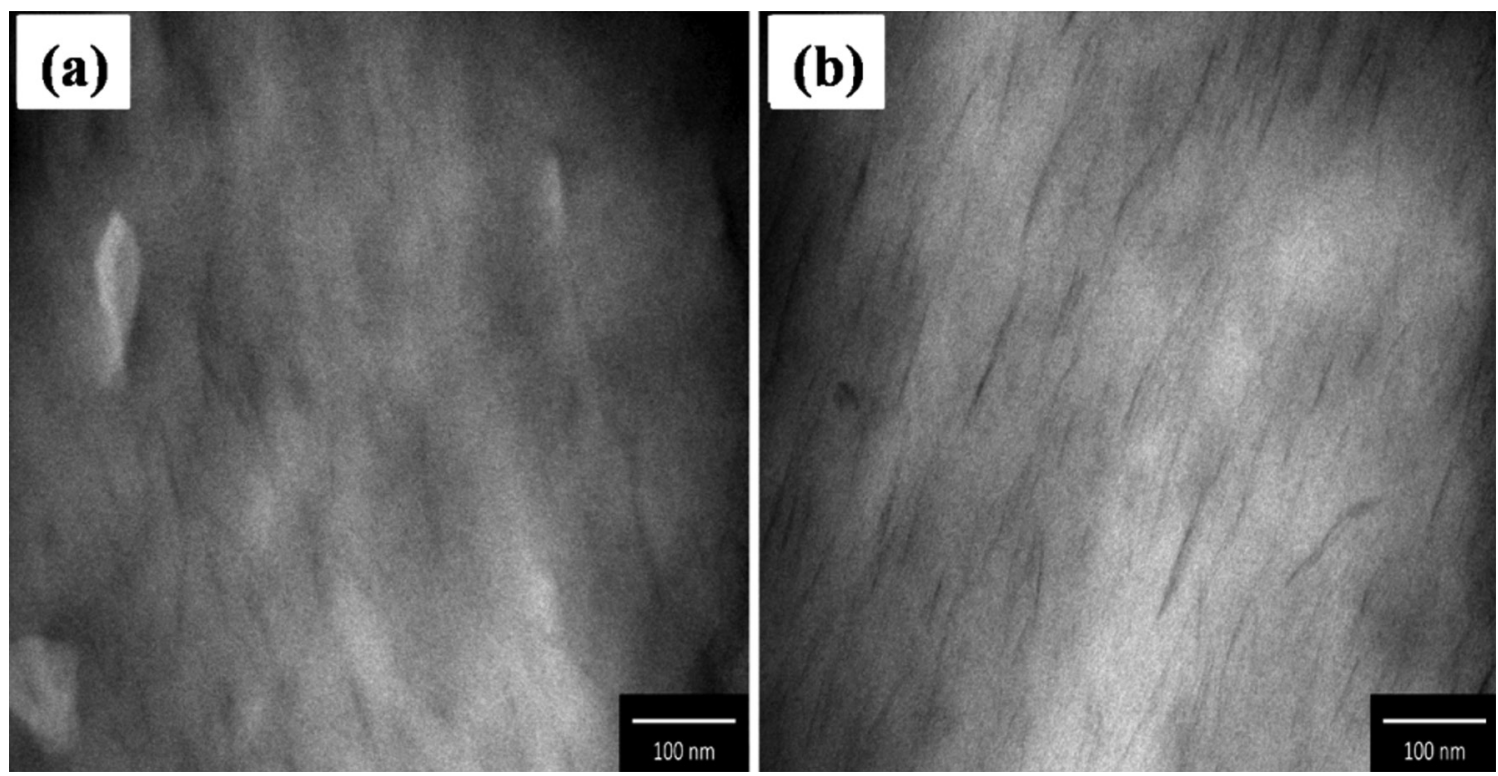

Figure 7. TEM photomicrographs of PA6 B400 nanocomposite with (a) $3 \%$, and (b) $5 \%$ organoclay.

Table 2. HDT of polyamide 6 with three viscosities indexes and their nanocomposites with 3 and $5 \%$ clay.

\begin{tabular}{ccr}
\hline Samples & Clay content $(\mathbf{\%})$ & HDT $\left({ }^{\circ} \mathbf{C}\right)$ \\
\hline \multirow{3}{*}{ C216 } & 0 & $102.1 \pm 8.4$ \\
& 3 & $152.6 \pm 3.0$ \\
& 5 & $193.7 \pm 0.8$ \\
\hline \multirow{3}{*}{ B300 } & 0 & $89.4 \pm 3.2$ \\
& 3 & $106.7 \pm 1.8$ \\
& 5 & $129.4 \pm 6.9$ \\
\hline \multirow{2}{*}{ B400 } & 0 & $97.6 \pm 0.8$ \\
& 3 & $110.0 \pm 3.7$ \\
\hline
\end{tabular}

increases the material stiffness and consequently increases the HDT values. In this case, clay considerably increased the HDT values of nanocomposites mainly with the $5 \%$ clay. In general, the HDT of polyamide was in the range of $96^{\circ} \mathrm{C}$ and the average nanocomposite with $3 \%$ clay, in the range of $123{ }^{\circ} \mathrm{C}$ and $5 \%$ clay around $174{ }^{\circ} \mathrm{C}$. From the point of view of application, the increase in this property is important for automotive, aeronautical industries, etc. The increases in systems B400 and C216 with 5\% loading demonstrate the nucleating effect of the clay in the polymer. The heat deflection temperature (HDT) is the temperature at which a polymer sample deforms under a specific load. This property is applied in many aspects of engineering and manufacturing of products. The incorporation of nanoscale clay generally increases the HDT of PA6 $6^{[11,12]}$. Shen et al. ${ }^{[28]}$ studied the effect of organoclay in the mechanical and thermal properties of the nanocomposites of polyamide 6 reinforced with glass fiber, and observed that clay caused an increase of approximately $65 \%$ in the HDT PA6/glass fiber/clay system.

The Figure 8 shows the DSC curves of polyamide 6 and its nanocomposites. In Figure $8 \mathrm{a}$ it can be observed that the
B300, B400, B300 3\%, C2163\% and B300 5\% compositions have different crystalline behaviors of other compositions. In Figure $8 \mathrm{~b}$, the crystallization temperatures practically unchanged for all samples. Already in Figure 8c, it can be observed that the melt peak shows a bimodal pattern of the endothermic peak in relation to pure PA6, and this pattern is seen with more intensity for compositions with increasing clay content. The endothermic peak $\mathrm{T}_{\mathrm{ml}}$ refers to $\alpha$ crystalline form of PA6. The presence of a second endothermic peak $\mathrm{T}_{\mathrm{m} 2}$, with temperatures slightly below the $\mathrm{T}_{\mathrm{m} 1}$, is related to the $\gamma$ crystalline form of PA6. These melt temperatures $\left(\mathrm{T}_{\mathrm{m} 1}\right.$ and $\left.\mathrm{T}_{\mathrm{m} 2}\right)$ suggest that $\alpha$ and $\gamma$ crystalline forms coexist in the nanocomposite. The $\gamma$ crystalline form may be associated with a decrease in the degree of packing of the crystalline domains. Therefore, the lower $\mathrm{T}_{\mathrm{m}}$ values of the nanocomposites can be attributed changes in lamellar size and distribution of the crystallites of PA6 $6^{[29-31]}$

Table 3 shows that the presence of the clay had minor changes in the crystallization temperature $\left(\mathrm{T}_{c}\right)$ when compared to $T_{c}$ of the pure polyamide. Probably the clay did not act as nucleating agent which can also be evidenced by the onset temperature of crystallization of the nanocomposites in relation to pure polymer. In general, it can be observed that the crystallinity degree $\left(\mathrm{X}_{\mathrm{c}}\right)$ of the nanocomposites decreased in relation to pure polymer. This can be attributed to interaction of the clay with the phase of the polyamide that restricted the mobility of the polymer chains hindering the crystallization process ${ }^{[33]}$.

Table 4 shows the results of mechanical properties of tensile polyamide 6 with three viscosities indexes and their nanocomposites with 3 and $5 \%$ of organoclay. It can be observed that the nanocomposites showed better mechanical properties under tensile as compared properties of polyamide 6 , i.e., the clay probably acted as reinforcing filler increasing the rigidity of the system, as it can be verified by the elastic modulus and yield stress. According 


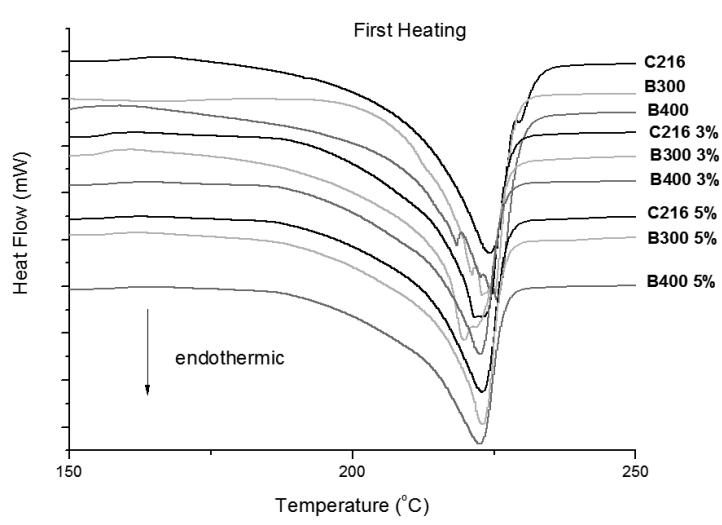

(a)

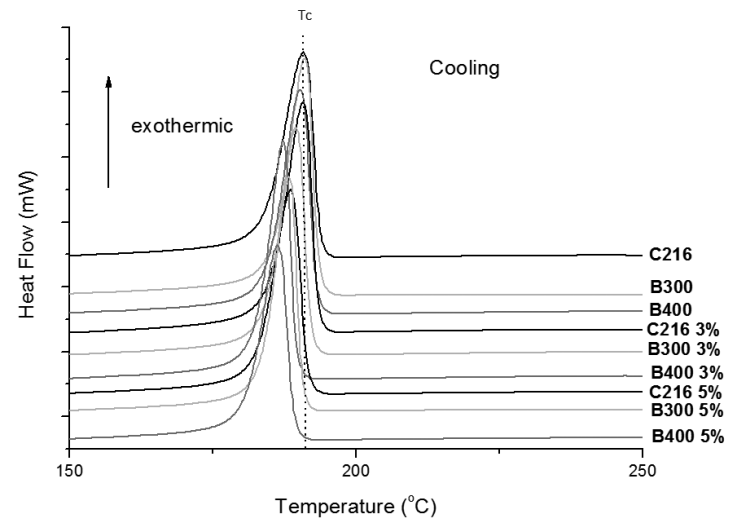

(b)

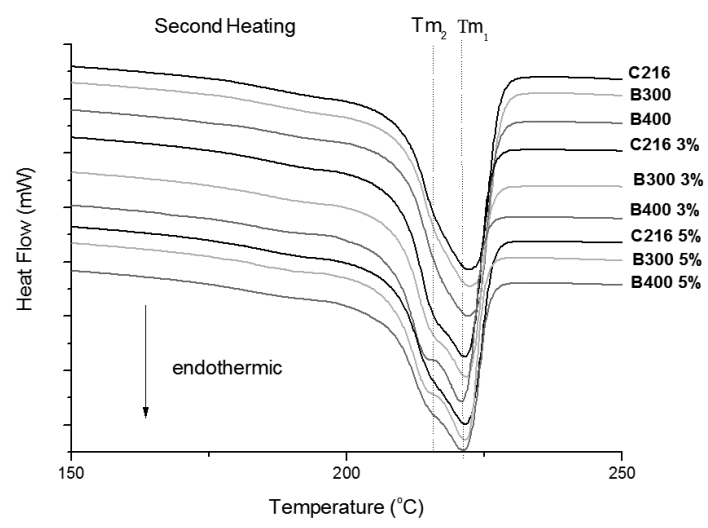

(c)

Figure 8. DSC curves (a) first heating, (b) cooling and (c) second heating of polyamide 6 with three viscosities indexes and their nanocomposites with 3 and $5 \%$ clay.

Table 3. Melting and crystallization parameters obtained for polyamide 6 with three viscosities indexes and their nanocomposites with 3 and $5 \%$ organoclay.

\begin{tabular}{|c|c|c|c|c|c|c|c|c|c|c|}
\hline \multirow[b]{2}{*}{ SAMPLE } & \multirow{2}{*}{$\begin{array}{c}\text { Clay } \\
\text { content } \\
(\%)\end{array}$} & \multicolumn{3}{|c|}{ First Heating } & \multicolumn{3}{|c|}{ Cooling } & \multicolumn{3}{|c|}{ Second Heating } \\
\hline & & $\begin{array}{l}\mathrm{T}_{\mathrm{m} 1} \\
\left({ }^{\circ} \mathrm{C}\right)\end{array}$ & $\begin{array}{c}X_{\mathrm{c} 1} \\
(\%)\end{array}$ & $\begin{array}{l}\Delta \mathbf{H}_{\mathrm{m} 1} \\
(\mathrm{~J} / \mathrm{g})\end{array}$ & $\begin{array}{c}\mathrm{T}_{\mathrm{c}} \\
\left({ }^{\circ} \mathrm{C}\right)\end{array}$ & $\begin{array}{l}\Delta \mathbf{H}_{\mathrm{c} 1} \\
(\mathrm{~J} / \mathrm{g})\end{array}$ & $\begin{array}{l}\mathrm{T}_{\text {onset }} \\
\left({ }^{\circ} \mathrm{C}\right)\end{array}$ & $\begin{array}{l}\mathrm{T}_{\mathrm{m} 2} \\
\left({ }^{\circ} \mathrm{C}\right)\end{array}$ & $\begin{array}{l}X_{c 2} \\
(\%)\end{array}$ & $\begin{array}{l}\Delta \mathbf{H}_{\mathrm{m} 2} \\
(\mathrm{~J} / \mathrm{g})\end{array}$ \\
\hline \multirow{3}{*}{ PA6C216 } & 0 & 224.3 & 46.5 & 87.5 & 190.8 & 66.8 & 195.9 & 222.1 & 38.2 & 71.9 \\
\hline & 3 & 221.4 & 37.2 & 69.9 & 190.7 & 65.2 & 195.4 & 223.0 & 36.1 & 67.8 \\
\hline & 5 & 222.9 & 33.6 & 66.4 & 188.6 & 59.2 & 194.1 & 221.3 & 32.6 & 64.6 \\
\hline \multirow{3}{*}{ PA6B300 } & 0 & 222.9 & 34.3 & 64.4 & 191.0 & 65.7 & 196.4 & 221.6 & 32.1 & 60.4 \\
\hline & 3 & 219.8 & 42.1 & 61.6 & 189.5 & 59.8 & 194.3 & 221.6 & 36.2 & 70.1 \\
\hline & 5 & 222.9 & 35.8 & 70.9 & 188.3 & 58.3 & 193.3 & 221.4 & 33.5 & 66.3 \\
\hline \multirow{3}{*}{ PA6B400 } & 0 & 225.5 & 47.3 & 88.9 & 190.3 & 64.9 & 196.1 & 221.9 & 39.7 & 74.7 \\
\hline & 3 & 222.5 & 32.6 & 63.2 & 187.3 & 58.3 & 191.7 & 220.8 & 32.7 & 63.4 \\
\hline & 5 & 222.6 & 30.9 & 61.2 & 186.2 & 57.6 & 191.4 & 221.1 & 33.7 & 66.8 \\
\hline
\end{tabular}

$\mathrm{T}_{\mathrm{m}}=$ Melting temperature taken at the melt peak; $\Delta \mathrm{H}_{\mathrm{c}}=$ Crystallization Enthalpy; $\Delta \mathrm{H}_{\mathrm{m}}=$ Heat of fusion, calculated from the melting peak; $\mathrm{T}_{\text {onset }}{ }^{\mathrm{m}}=$ onset temperature. $\mathrm{X}_{\mathrm{c}}=$ Degree of crystallinity obtained by DSC, taken from $\Delta \mathrm{HF} / \Delta \mathrm{HF} 100 \% ; \Delta \mathrm{HF} 100=$ heat of fusion for PA6, $100 \%$ crystalline, $188 \mathrm{~J} / \mathrm{g}^{[32]}$.

to Sinha Ray and Okamoto ${ }^{[9]}$ and Alexandre and Dubois ${ }^{[13]}$ and, the system formed by polymer/clay containing low clay content $(<10 \%)$ exhibit better mechanical properties compared to pure polyamide. This increase is because of the stronger interfacial interaction between the matrix and the clay layers, especially when they are more dispersed 10. On the other hand, the elongation at break decreased, as expected, due to the particles of the clay acted as a barrier preventing the mobility of the polymer chains and reducing the elongation ${ }^{[15,24]}$. 
Table 4. Mechanical properties obtained of polyamide 6 with three viscosities indexes and their nanocomposites with 3 and $5 \%$ organoclay.

\begin{tabular}{|c|c|c|c|c|}
\hline Samples & $\begin{array}{c}\text { Clay Content } \\
(\%)\end{array}$ & $\begin{array}{c}\text { Module } \\
\text { (GPa) }\end{array}$ & Yield stress (MPa) & $\begin{array}{c}\text { Elongation } \\
\text { at break } \\
(\%) \\
\end{array}$ \\
\hline \multirow{3}{*}{$\mathrm{C} 216$} & 0 & $3.3 \pm 0.0$ & $67.7 \pm 1.1$ & $38.5 \pm 1.7$ \\
\hline & 3 & $3.5 \pm 0.1$ & $66.4 \pm 1.5$ & $25.6 \pm 2.0$ \\
\hline & 5 & $4.8 \pm 0.1$ & $81.2 \pm 4.7$ & $8.1 \pm 0.8$ \\
\hline \multirow{3}{*}{ B300 } & 0 & $3.6 \pm 0.0$ & $75.1 \pm 1.6$ & $12.1 \pm 0.5$ \\
\hline & 3 & $3.9 \pm 0.1$ & $86.0 \pm 1.2$ & $7.7 \pm 0.3$ \\
\hline & 5 & $4.1 \pm 0.2$ & $85.1 \pm 1.1$ & $4.6 \pm 0.4$ \\
\hline \multirow{3}{*}{ B400 } & 0 & $3.7 \pm 0.1$ & $72.4 \pm 0.5$ & $14.2 \pm 0.9$ \\
\hline & 3 & $3.8 \pm 0.2$ & $75.9 \pm 1.1$ & $10.3 \pm 0.6$ \\
\hline & 5 & $4.0 \pm 0.2$ & $82.3 \pm 1.4$ & $9.9 \pm 0.5$ \\
\hline
\end{tabular}

\section{Conclusions}

Nanocomposites of polyamide 6 with three viscosities indexes and a Brazilian organoclay were produced and the mechanical, thermal and thermomechanical properties were evaluated. By XRD, the peak of the organoclay disappeared when incorporated into polyamide 6 indicating that all systems had exfoliated and/or partially exfoliated structures. TEM photomicrographs confirmed these structures. By TG, nanocomposites showed higher thermal stability in relation to pure polymer. The nanocomposites showed HDT values significantly higher than that of pure polyamide 6 . The nanocomposites with $5 \%$ clay had better tensile mechanical properties when compared to the nanocomposites with $3 \%$ and pure polyamides. In other words, the clay acted as reinforcing filler increasing the rigidity of the system. The mechanical properties (modulus and yield stress) increased with the presence of organoclay. The three viscosities indexes of PA6 and two contents of clay influenced the structure and properties of the systems, ie, the Brazilian clay had an important role in the final properties of HDT because there was an $100 \%$ increase in the system HDT in comparison with the pure polymer.

\section{Acknowledgements}

The authors thank Rhodia/SP, Bentonit União Nordeste (BUN), DEMa/UFCG and DEMa/UFSCar, CAPES/PNPD, $\mathrm{MCTI} / \mathrm{CNPq}$ for the financial support.

\section{References}

1. Shi, H., Lan, T., \& Pinnavaia, T. J. (1996). Interfacial effects on the reinforcement properties of polymer organoclay nanocomposite. Chemistry of Materials, 8(8), 1584-1587. http://dx.doi.org/10.1021/cm960227m.

2. Souza Santos, P. (1989). Ciência e tecnologia de argilas. 2nd ed. São Paulo: Edgar Blucher.

3. Fornes, T. D., \& Paul, D. R. (2003). Crystallization behavior of nylon 6 nanocomposites. Polymer, 44(14), 3945-3961. http:// dx.doi.org/10.1016/S0032-3861(03)00344-6.

4. García-López, D., Fernández, J. F., Merino, J. C., \& Pastor, J. M. (2013). Influence of organic modifier characteristic on the mechanical properties of polyamide 6/organosepiolite nanocomposites. Composites. Part B, Engineering, 45(1), 459-464. http://dx.doi.org/10.1016/j.compositesb.2012.09.087.
5. Pavlidou, S., \& Papaspyrides, C. D. (2008). A review on polymer-layered silicate nanocomposites. Progress in Polymer Science, 33(12), 1119-1198. http://dx.doi.org/10.1016/j. progpolymsci.2008.07.008.

6. Mészáros, L., Deák, T., Balogh, G., Czvikovszky, T., \& Czigány, T. (2013). Preparation and mechanical properties of injection moulded polyamide 6 matrix hybrid nanocomposite. Composites Science and Technology, 75(11), 22-27. http:// dx.doi.org/10.1016/j.compscitech.2012.11.013.

7. Barbosa, R., Morais, D. D. S., Nóbrega, K. C., Araújo, E. M., \& Mélo, T. J. A. (2012). Influence of processing variables on the mechanical behavior of HDPE/clay nanocomposites. Materials Research, 15(3), 477-482. http://dx.doi.org/10.1590/ S1516-14392012005000054.

8. Paz, R. A., Araújo, E. M., Pessan, L. A., Melo, T. J. A., Leite, A. M. D. \& Medeiros, V. N. (2012). Influence of molecular weight of polyamide 6 in obtaining of nanocomposites with national organoclay. Materials Science Forum, 727, 1711-1777. Retrieved in 15 April 2014, from 10.4028/www.scientific.net/ MSF.727-728.1711

9. Sinha Ray, S., \& Okamoto, M. (2003). Polymer/layered silicate nanocomposites: a review from preparation to processing. Progress in Polymer Science, 28(11), 1539-1568. http://dx.doi. org/10.1016/j.progpolymsci.2003.08.002.

10. Fornes, T. D., Yoon, P. J., Keskkula, H., \& Paul, D. R. (2001). Nylon 6 nanocomposites: the effect of matrix molecular weight. Polymer, 42(25), 9929-9940. http://dx.doi.org/10.1016/S00323861(01)00552-3.

11. Paz, R. A., Leite, A. M. D., Araújo, E. M., Melo, T. J. A., \& Pessan, L. A. (2010). Avaliação do comportamento térmico por DSC na Região da pele e do Núcleo de Amostras Injetadas de Nanocompósitos de Poliamida 6/Argila Organofílica. Polímeros, 20(4), 258-262. http://dx.doi.org/10.1590/S010414282010005000043

12. Kojima, Y., Usuki, A., Kawasumi, M., Okada, A., Fukushima, Y., Kurauchi, T., \& Kamigaito, O. (1993). Mechanical properties of polyamide 6-clay hybrid. Journal of Materials Research, 8(5), 5-11. http://dx.doi.org/10.1557/JMR.1993.1185.

13. Alexandre, M. \& Dubois, P. (2000). Polymer-layered silicate nanocomposites; preparation, properties and uses of a new class of montmorillonite. Materials Science and Engineering, 28, 1-63. http://dx.doi.org/S0927796X(00)000127.

14. Ayres, E., \& Oréfice, R. L. (2007). Nanocompósitos derivados de dispersões aquosas de poliuretano e argila: influência da argila na morfologia e propriedades mecânicas. Polímeros, 17(4), 339-344. http://dx.doi.org/10.1590/S0104-14282007000400015.

15. Paz, R. A., Araújo, E. M., Pessan, L. A., Melo, T. J. A., Leite, A. D., \& Medeiros, V. N. (2012). Evaluation of impact strength 
of polyamide 6/bentonite clay nanocomposites. Materials Research, 15(4), 506-510. http://dx.doi.org/10.1590/S151614392012005000066.

16. Vaia, R. A., \& Maguire, J. F. (2007). Polymer nanocomposites with prescribed morphology: going beyond nanoparticle-filled polymers. Chemistry of Materials, 19(11), 2736-2742. http:// dx.doi.org/10.1021/cm062693+.

17. Krishnamoorti, R., \& Vaia, R. A. (2007). Polymer nanocomposites. Journal of Polymer Science. Part B, Polymer Physics, 45(24), 3252-3259. http://dx.doi.org/10.1002/polb.21319.

18. Chavarria, F., \& Paul, D. R. (2006). Morphology and properties of thermoplastic polyurethane nanocomposites: Effect of organoclay structure. Polymer, 47(22), 7760-7766. http:// dx.doi.org/10.1016/j.polymer.2006.08.067.

19. Noda, N., Lee, Y.-H., Bur, A. J., Prabhu, V. M., Snyder, C. R., Roth, S. C., \& McBrearty, M. (2005). Dielectric properties of nylon 6/clay nanocomposites from on-line process monitoring and off-line measurements. Polymer, 46(18), 7201-7217. http:// dx.doi.org/10.1016/j.polymer.2005.06.046.

20. Yoo, Y., \& Paul, D. R. (2008). Effect of organoclay structure on morphology and properties of nanocomposites based on an amorphous polyamide. Polymer, 49(17), 3795-3804. http:// dx.doi.org/10.1016/j.polymer.2008.06.014.

21. Vlasveld, D. P. N., Groenewold, J., Bersee, H. E. N., \& Picken, S. J. (2005). Moisture absorption in polyamide-6 silicate nanocomposites and its influence on the mechanical properties. Polymer, 46(26), 12567-12576. http://dx.doi.org/10.1016/j. polymer.2005.10.096.

22. Díaz, V. F. R. (2001). Preparation of organophilic clays from a Brazilian smectitic clay. Key Engineering Materials. 189191, 203-207. http://dx.doi.org/10.4028/www.scientific.net/ KEM.189-191.203.

23. Díaz, V. F. R. (1994). Preparação a nivel de laboratório de algumas argilas esmectíticas organofilicas (Tese de doutorado). Departamento de Engenharia Química, Escola Politécnica, Universidade de São Paulo, São Paulo.

24. Paz, R. A., Leite, A. M. D., Araujo, E. M., Melo, T. J. A., Pessan, L. A., \& Passador, F. R. (2013). Propriedades mecânicas e reológicas de nanocompósitos de poliamida $6 \mathrm{com}$ argila Organofílica Nacional. Polímeros: Ciência e Tecnologia, 23(5), 682-689. http://dx.doi.org/10.4322/polimeros.2013.060.

25. Andrade, D. L. A. C. S. (2003). Desenvolvimento de nanocompósitos polipropileno/bentonita através da técnica de intercalação por fusão (Dissertação de mestrado). Universidade Federal de Campina Grande, Paraíba.

26. Lewin, M., Pearce, M. E., Levon, K., Mey-Marom, A., Zammarano, M., Wilkie, C. A., \& Jang, B. N. (2006). Nanocomposites at elevated temperatures: migration and structural changes. Polymers for Advanced Technologies, 17(4), 226-234. http:// dx.doi.org/10.1002/pat.684.

27. Chiu, F. C., Lai, S. M., Chen, Y. L., \& Lee, T. H. (2005). Investigation on the polyamide 6/organoclay nanocomposites with or without a maleated polyolefin elastomer as a toughener. Polymer, 46(25), 11600-11609. http://dx.doi.org/10.1016/j. polymer.2005.09.077.

28. Shen, S. Z., Bateman, S., Mcmahon, P., Dell'olio, M., Gotama, J., Nguyen, T. \& Yuan, Q. (2010). The effects of Clay on fire performance and thermal mechanical properties of woven glass fibre reinforced polyamide 6 nanocomposites. Composites Science and Technology, 70(14), 2063-2067. http://dx.doi. org/10.1016/j.compscitech.2010.07.027.

29. González, T. V., Salazar, C. G., Rosa, J. R., \& González, V. G. (2008). Nylon 6/organoclay nanocomposites by extrusion. Journal of Applied Polymer Science, 108(5), 2923-2933. http:// dx.doi.org/10.1002/app.27307.

30. Li, T.-C., Ma, J., Wang, M., Tjiu, W. C., Liu, T., \& Huang, W. (2007). Effect of Clay Addition on the Morphology and Thermal Behavior of Polyamide 6. Journal of Applied Polymer Science, 103(2), 1191-1199. http://dx.doi.org/10.1002/app.25378.

31. Oliveira, M. F. L., Oliveira, M. G., \& Leite, M. C. A. M. (2011). Nanocompósitos de poliamida 6 e argila organofílica: estudo da cristalinidade e propriedades mecânicas. Polímeros: Ciência e Tecnologia, 21(1), 78-82. http://dx.doi.org/10.1590/ S0104-14282011005000015.

32. Kohan, M. I. (1973). Nylon plastics (p. 683). New York: John Wiley \& Sons.

33. Yu, S., Zhao, J., Chen, G., Juay, Y. K., \& Yong, M. S. (2007). The characteristics of polyamide layered-silicate nanocomposites. Journal of Materials Processing Technology, 192-193(1), 410414. http://dx.doi.org/10.1016/j.jmatprotec.2007.04.006.

Received: Apr. 15, 2014

Revised: July 27, 2015

Accepted: Sept. 08, 2015 